\title{
In vitro germination of pollen grains of three native species from Pampa biome with ornamental potential
}

\author{
Marília Tedesco*(D), Luciano da Silva Alves(D, Eduarda Demari Avrella(D, \\ Carine Simioni(D, Gilmar Schafer(D)
}

Federal University of Rio Grande do Sul, Porto Alegre, Brazil

*Corresponding author, e-mail: marilia_tedesco@hotmail.com

\begin{abstract}
The aim of this work was to verify the in vitro germination of pollen grains of Angelonia integerrima L., Campomanesia aurea O. Berg and Sesbania punicea (Cav.) Benth in different culture medium and temperatures. For this purpose, flower buds from which pollen was collected and sprayed on plates containing the three evaluated culture medium: $\mathrm{Ml}$ - agar and sucrose; $\mathrm{M} 2$ - agar, sucrose and $\mathrm{H}_{3} \mathrm{BO}_{3^{\prime}} ; \mathrm{M} 3$ - agar, sucrose, $\mathrm{H}_{3} \mathrm{BO}_{3^{\prime}}$ $\mathrm{Ca}\left(\mathrm{NO}_{3}\right), \mathrm{MgSO}_{4}$ and $\mathrm{KNO}_{3}$; and two incubation temperatures $\left(20^{\circ} \mathrm{C}\right.$ and $\left.30^{\circ} \mathrm{C}\right)$. Data was subjected to analysis of variance after its transformation to square root and means were compared by Fisher's test (LSD). For the three species, the temperature of $30^{\circ} \mathrm{C}$ provided the highest percentage of pollen grain germination. For $A$. integerrima, $\mathrm{Ml}$ and $\mathrm{M} 3$ promoted the highest germination percentages ( $40.7 \%$ and $56.5 \%$, respectively). On the other hand, for C. aurea, M2 provided the highest germination average (43.7 \%). At last for S. punicea, M3 was the one that provided the highest average (31.62\%). It was concluded that the evaluated species differ in micronutrient requirements for in vitro germination of pollen grains. The temperature of $30^{\circ} \mathrm{C}$ was suitable for all three species.
\end{abstract}

Keywords: Angelonia integerrima L., Campomanesia aurea O. Berg, floriculture, pollen tube, Sesbania punicea (Cav.) Benth

The Pampa biome is characterized by its high species richness, and Boldrini et al. (2015) described the existence of approximately 2,150 higher plant species in this biome. In a study by Stumpf et al. (2012), at least 250 species from the Pampa biome were recognized due to their ornamental potential for using in floral art and landscaping.

The usage of native species as ornamental plants has emerged as a new niche in the floriculture market, showing a high potential for production and commercialization. These species have some advantages over the exotic ones, such as greater adaptation to local edaphoclimatic conditions (Oliveira Junior et al., 2013), besides showing a singular beauty within a market already saturated by traditional crops. In addition, floriculture can directly contribute to the in situ preservation of native germplasm (Nahoum \& Fraga, 2015), especially in species that are the target of extractivism, since if adequately propagated and marketed, the indiscriminate collection of these material in the wild will decrease.

Among the native species of the Pampa biome with ornamental potential, some have been highlighted because of their characteristics such as the size, architecture, color and aroma of flowers, such as: Angelonia integerrima Spreng. (Plantaginaceae), Campomanesia aurea O. Berg (Myrtaceae) and Sesbania punicea (Cav.) Benth (Fabaceae). These three species and their attributes were introduced by Stumpf et al. (2009) in the book "Colors and Shapes in the Pampa Biome: Native Ornamental Plants".

For commercial purposes, studies on the in vitro germination capacity of genotype pollen grains of a species may presuppose the success of their use in further crosses (Chagas et al., 2010), with the objective of obtaining a material with even more interesting characteristics. 
The conditions required for pollen germination differs among species, especially concerning the culture medium components, temperature and incubation time (Stanley \& Linskens, 1974). Regarding the culture medium, it must be composed of organic and inorganic elements, in order to provide to pollen with a condition similar to that found in the flower stigma (Sousa et al., 2010; Silva et al., 2017).

So far, there was a lack of knowledge about adequate conditions for in vitro germination tests for pollen of A. integerrima, C. aurea and S. punicea. Thus, the aim of this work was to observe the in vitro germination of pollen grains of these three species in different culture medium and temperatures.

The plant material used was flower buds collected in November 2018 of 15 individuals from a population of C. aurea and of 25 individuals from a population of $A$. integerrima, both located in Parque Natural Morro do Osso, in Porto Alegre city - state of Rio Grande do Sul. Also was collected flower buds of 15 individuals from a population of $S$. punicea located in an area adjacent to the road in the municipality of Palmares do Sul, state of Rio Grande do Sul, in December 2018. The project is registered with SisGen under number A685CD8.

Once collected, the material was immediately packed in Styrofoam boxes and transported to the laboratory, where flower buds were manually sorted, keeping only those that were in a balloon stage (preanthesis). The buds were then placed on trays lined with absorbent paper in a B.O.D. (Biochemical Oxygen Demand) chamber at $30^{\circ} \mathrm{C}$ in the dark for 24 hours for pollen drying. Subsequently, the petals were removed and the anthers were exposed to incandescent light for 20 minutes for complete dehiscence and pollen release.

Three culture medium expressed in a concentration for $100 \mathrm{ml}$ of autoclaved deionized water were tested: Medium 1 (M1) - $10 \mathrm{~g}$ sucrose + $1 \mathrm{~g}$ agar (standard culture medium); Medium 2 (M2) - $10 \mathrm{~g}$ sucrose $+1 \mathrm{~g}$ agar $+0.08 \mathrm{~g} \mathrm{H}_{3} \mathrm{BO}_{3}$ (Franzon et al., 2006); and Medium 3 (M3) - $15 \mathrm{~g}$ sucrose $+1 \mathrm{~g}$ agar $+0.01 \mathrm{~g}$ $\mathrm{H}_{3} \mathrm{BO}_{3}+0.1 \mathrm{~g} \mathrm{Ca}\left(\mathrm{NO}_{3}\right) .4 \mathrm{H}_{2} \mathrm{O}+0.03 \mathrm{~g} \mathrm{MgSO}_{4} .7 \mathrm{H}_{2} \mathrm{O}+0.01$ $\mathrm{g} \mathrm{KNO}_{3}$ (Sahar \& Spiegel-Roy, 1984); and two incubation temperatures: $20^{\circ} \mathrm{C}$ and $30^{\circ} \mathrm{C}$.

For the preparation of the culture medium, the constituent elements were dissolved in deionized water and heated on a magnetic stirrer at a temperature of approximately $90^{\circ} \mathrm{C}$ and then poured into cell culture plates (35 mm $\times 12 \mathrm{~mm}$ ) coupled to microscopy slides. After solidification of the medium, the pollen was removed from the anthers with the aid of a number-4 brush and sprayed all over the surface of the plate. The plates/slides were then kept in gerbox-type boxes with moist Germitest paper simulating a wet chamber and incubated in B.O.D. chamber for 12 hours in the dark at both temperatures.

The germinated pollen grains (which emitted the longest pollen tube, twice the pollen diameter, at least) were counted with the aid of optical microscope with 20-x magnification, on which 500 pollen grains per plate/ slide were observed.

The study used a completely randomized design in a $3 \times 2$ factorial arrangement, with three culture medium (M1, M2 and M3) and two incubation temperatures (20 ${ }^{\circ} \mathrm{C}$ and $30{ }^{\circ} \mathrm{C}$ ), with four replications (each plate/slide corresponding to one repetition). Data was subjected to analysis of variance after transformation to square root, and then means were compared by Fisher's test (LSD) at $5 \%$ probability of error. The analysis was performed using Sigmaplot 11.0 software.

For A. integerrima (Figure 1A), interaction was found between culture medium and incubation temperature (p-value <0.001). The germination percentage did not differ between culture medium at 20 ${ }^{\circ} \mathrm{C}$, with an average of only $0.9 \%$ of germinated pollens (Table 1). However, when the temperature was $30^{\circ} \mathrm{C}$, a difference between the media was found, in which $\mathrm{M} 2$ medium was the one with the lowest average, while the M1 and M3 medium increased the germination by 6.2 and 8.6 times compared to $M 2$, respectively (Table 1).

For C. aurea (Figure 1C), no pollen grain germinated at $20^{\circ} \mathrm{C}$ (Table 1). At $30^{\circ} \mathrm{C}, \mathrm{M} 2$ provided the highest average of germinated pollens, increasing the germination by 6.6 times when compared to $M 3$ (which resulted in the lowest average), but both did not differ from M1, which provided a germination of $20 \%$ (Table 1).

On the other hand, no interaction was found between the factors (p-value: 0.384) for S. punicea (Figure 1E); only the effect of the isolated factors. The highest germination means were obtained with $M 3$, which provided a germination increment of about 50 times in germination in comparison with $\mathrm{Ml}$ and the temperature of $30^{\circ} \mathrm{C}$, which caused twice the germination in relation to the temperature of $20^{\circ} \mathrm{C}$ (Table 2).

The M1, composed only by agar and sucrose, and the M3, the most complete, provided the highest percentages of pollen grain germination for species $A$. integerrima in this study, therefore, indicating that these species do not need addition of micronutrients for pollen germination.

For the species Syagrus romanzoffiana (S.) Cham (jerivá - Arecaceae), Sousa et al. (2010) found that the 

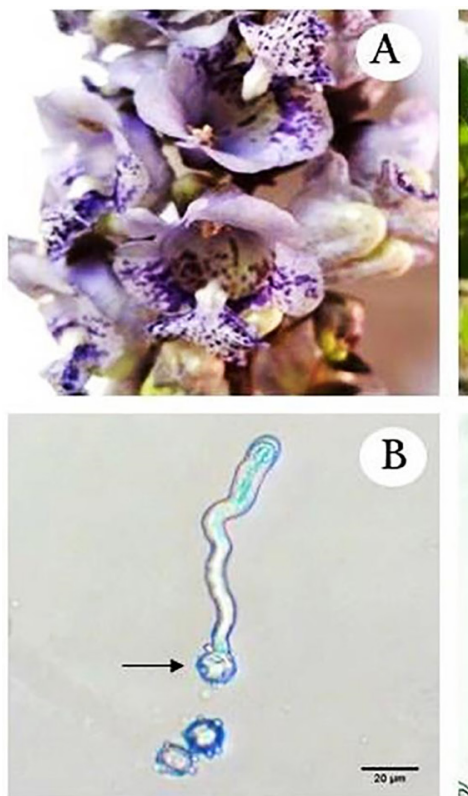

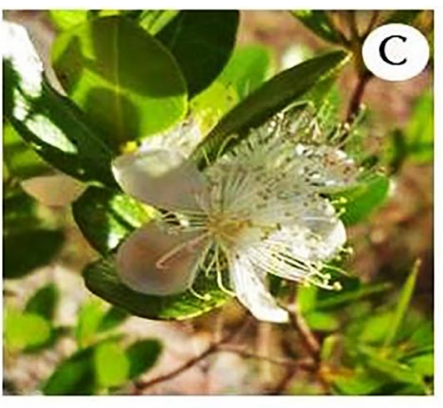

$\mathrm{D}$

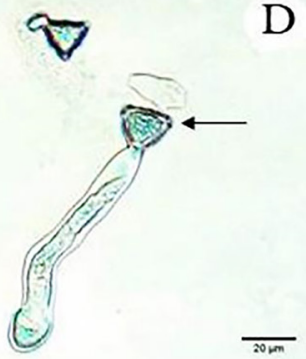

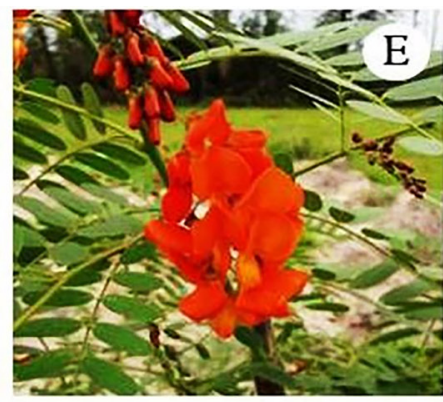

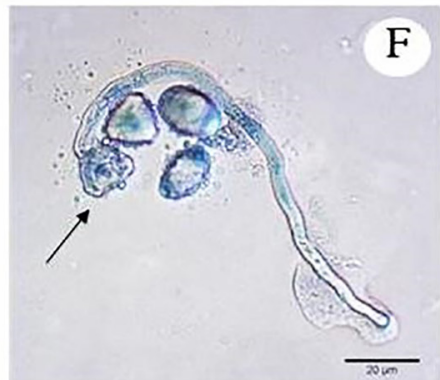

Figure 1. In vitro germination of pollen grains after 12 hours of incubation from Angelonia integerrima Spreng., Campomanesia aurea O. Berg and Sesbania punicea (Cav.): A) detail of inflorescence A. integerrima; B) germinated (arrow) and non-germinated pollen grains of A. integerrima; C) detail of C. aurea flower; D) germinated (arrow) and non-germinated pollen grain of C. aurea; E) detail of $S$. punicea inflorescence; F) germinated (arrow) and non-germinated pollen grains of S. punicea.

Table 1. Average percentage of in vitro pollen germination of Angelonia integerrima Spreng. and Campomanesia aurea $\mathrm{O}$. Berg in different culture medium and temperatures

\begin{tabular}{|c|c|c|c|}
\hline \multirow[b]{2}{*}{ Species } & \multirow[b]{2}{*}{ Culture medium } & \multicolumn{2}{|c|}{ Incubation temperature } \\
\hline & & $20^{\circ} \mathrm{C}$ & $30^{\circ} \mathrm{C}$ \\
\hline \multirow{3}{*}{ Angelonia integerrima } & Ml & $1.2 \mathrm{aB}$ & $40.7 \mathrm{aA}$ \\
\hline & M2 & $0.5 \mathrm{aB}$ & $6.55 \mathrm{bA}$ \\
\hline & M3 & $1.0 \mathrm{aB}$ & $56.5 \mathrm{aA}$ \\
\hline \multirow{3}{*}{ Campomanesia aurea } & Ml & $0 a B$ & $20 \mathrm{abA}$ \\
\hline & $M 2$ & $0 a B$ & $43.7 \mathrm{aA}$ \\
\hline & M3 & $0 \mathrm{aB}$ & $8.05 \mathrm{bA}$ \\
\hline
\end{tabular}

Table 2. Average percentage of in vitro germination of pollen from Sesbania punicea (Cav.) Benth in different culture medium and temperatures

\begin{tabular}{|c|c|c|}
\hline \multirow{7}{*}{$\begin{array}{l}\text { Sesbania } \\
\text { punicea }\end{array}$} & Culture medium & Germination (\%) \\
\hline & Ml & $0.65 c$ \\
\hline & $M 2$ & $3.85 b$ \\
\hline & M3 & $31.62 \mathrm{a}$ \\
\hline & Incubation temperature & \\
\hline & $20^{\circ} \mathrm{C}$ & $8.2 \mathrm{~b}$ \\
\hline & $30^{\circ} \mathrm{C}$ & $15.9 \mathrm{a}$ \\
\hline
\end{tabular}

medium composed only of agar and sucrose provided the highest percentage of in vitro germination of pollen grains.

When boron is added to the medium as boric acid, it promotes the formation of a sugar-borate ionizable complex which interacts with cell membranes, resulting in an increase in the germination percentage and pollen tube length (Thompson \& Batjer, 1950). This element may have been responsible for the increased germination in C. aurea, since $M 2$, composed of agar, sucrose and boric acid, provided the highest germination mean in these species. Although M3 also contains boric acid in its constitution, the interaction with the other constituent elements of this medium may have been detrimental to the germination of pollen grains of $C$. aurea.

Regarding native species of the Myrtaceae family, differences are found in relation to the pollen behavior with regard to culture medium. For Campomanesia xanthocarpa Mart. ex O. Berg (guabirobeira), three different culture medium were tested and did not differ, indicating that boron did not influence the average pollen germination for this species, while for Eugenia uniflora L. the medium composed by sucrose and agar provided the best in vitro germination averages (Franzon et al., 2006). For jabuticaba trees of genus Plinia L., the addition of boric acid in the culture medium increased in vitro pollen germination (Danner et al., 2011).

In addition do agar, sucrose and boric acid, M3 is composed of calcium nitrate, magnesium sulfate and potassium nitrate. It provided the highest germination percentage in S. punicea, suggesting that this species 
needs micronutrients to stimulate germination of pollen grains. Calcium, one of the constituent elements of this medium, may have been responsible for this result, as it is especially important for pollen tube growth (Sousa ef al., 2010).

It can be seen on Figures 1B, 1D and IF that, after 12 hours of incubation, the pollen tubes reached about 8 to 10 times the pollen grain size, indicating that this time was sufficient for germination evaluation.

Plants, being sessile organisms, are more frequently influenced by environmental factors such as drought, cold, salinity and high temperatures, which can considerably affect the success of reproduction and fertilization processes (Giorno et al., 2013).

For the three species studied, the temperature of $20^{\circ} \mathrm{C}$ provided a minimum percentage of germinated pollens, including the absence of grains germinated for c. aurea. These results show that low temperatures are not suitable for pollen grain germination in these species. In pollen grains, the effect of low temperatures is related to the reduction of cellular metabolism (Cuchiara et al., 2012), which ends up affecting the essential processes that initiate the germination of the pollen tube.

According to Karni \& Aloni (2002), the development and germination of pollen depend on the uptake and metabolism of carbohydrates by it, and the temperature can interfere in this process (Aloni, 2001). In the present study, the temperature of $30{ }^{\circ} \mathrm{C}$ may have promoted an increase in metabolic activity and a concomitant decrease in the internal potential of the pollen, promoting greater absorption of water, sucrose and nutrients from the culture medium, thus facilitating the germination process of the pollen tube. Furthermore, the three species bloom in the spring months (between September and November), where the maximum average temperatures approach $30^{\circ} \mathrm{C}$ (in the referred collection municipalities), this may explain the requirement of higher temperatures for the in vitro germination of pollen grains.

For many species, temperatures between $25^{\circ} \mathrm{C}$ and $30^{\circ} \mathrm{C}$ are considered ideal for pollen germination, such as for Eugenia involucrata DC. (Myrtaceae) (Franzon et al., 2007), Campomanesia xanthocarpa (Myrtaceae) (Franzon et al., 2006), Olea europaea L. (Oleaceae) (Silva et al., 2016), among others.

For the three species studied in the present work, pollen grain germination ranged from 31.6 to $56.5 \%$ for the medium that provided the highest averages, values considered satisfactory for in vitro germination tests (Franzon et al., 2006; Danner et al., 2011). Considering that several factors influence pollen grain germination, some adjustments may be made in further works, such as the evaluation of different temperatures, micronutrient concentrations and flower stage, which may further increase the germination percentage.

It was concluded that the evaluated species differ in micronutrient requirements for in vitro germination of pollen grains, in which $M 1$ and $M 3$ were the best medium for $A$. integerrima, $M 2$ for $C$. aurea and $M 3$ for $S$. punicea, and temperature $30^{\circ} \mathrm{C}$ was suitable for all three species.

\section{Acknowledgments}

We are grateful to the Conselho Nacional de Desenvolvimento Científico e Tecnológico (CNPq) and Fundação de Amparo à Pesquisa do Estado do Rio Grande do Sul (FAPERGS) for financial support.

\section{References}

Aloni, B., Peet, M.M., Pharr, M., Karni, L. 2001. The effect of high temperature and high atmospheric $\mathrm{CO}_{2}$ on carbohydrate changes in bell pepper (Capsicum annuum) pollen in relation to its germination. Acta Physiologiae Plantarum 112: 505-512.

Boldrini, I., Overbeck, G., Trevisan, R. 2015. Biodiversidade de plantas. In: Pillar, V.P., Lange, O. Os campos do sul. Rede Campos Sulinos/UFRGS, Porto Alegre, Brazil. p. 5160.

Chagas, E.A., Pio, R., Chagas, P.C., Pasqual, M., Bettiol Neto, J.E. 2010. Composição do meio de cultura e condições ambientais para germinação de grãos de pólen de porta-enxertos de pereira. Ciência Rural 40: 261-266.

Cuchiara, C.C., Silva, S.D.A., Bobrowski, V.L. 2012. Conservação de grãos de pólen de mamoneira a baixas temperaturas. Revista Ceres 59: 82-87.

Danner, M.A., Citadin, I., Sasso, S.A.Z., Sachet, M.R., Malagi, G. 2011 . Modo de reprodução e viabilidade de pólen de três espécies de jabuticabeira. Revista Brasileira de Fruticultura 33: 345-352.

Franzon, R.C., Raseira, M.C.B., Wagner Junior, A. 2006. Germinação in vitro de pólen de guabirobeira (Campomanesia xanthocarpa Berg). Revista Ceres 53: 129-134.

Franzon, R.C., Raseira, M.C.B., Wagner, J.A. 2007. Testes de germinação in vitro e armazenamento de pólen de pitangueira (Eugenia uniflora L.). Acta ScientiarumAgronomy 29: 251-255.

Giorno, F., Wolters-Arts, M., Mariani, C., Rieu, I. 2013. Ensuring reproduction at high temperatures: the heat stress response during anther and pollen development. Plants 2: 489-506.

Karni, L., Aloni, B. 2002. Fructokinase and hexokinase from pollen grains of bell pepper (Capsicum annuum L.): Possible role in pollen germination under conditions of 
high temperature and $\mathrm{CO}_{2}$ enrichment. Annals of Botany 90: 607-612.

Nahoum, P., Fraga, C.N. 2015. Uso de Recursos Fitogenéticos no Paisagismo. In: Veiga, R.F.A, Queiróz, M.A. Recursos Fitogenéticos - A base da Agricultura Sustentável no Brasil. UFV, Viçosa, Brazil. p. 306-313.

Oliveira Júnior, C.J.F., Gonçalves, F.S., Couto, F., Matajs, L. 2013. Potencial das espécies nativas na produção de plantas ornamentais e paisagismo agroecológico. Revista Brasileira de Agroecologia 8: 190-200.

Sahar, N., Spiegel-Roy, P. 1984. In vitro germination of avocado pollen. Scientia Horticulturae 19: 886-888.

Silva, L.F.O., Zambon, C.R., Pio, R., Oliveira, A.F., Gonçalves, E.D. 2016. Establishment of growth medium and quantification of pollen grains of olive cultivars in Brazil's subtropical areas. Bragantia 75: 26-32.

Silva, D.F., Pio, R., Nogueira, P.V., Silva, P.A.O., Figueiredo, A.L. 2017. Viabilidade polínica e quantificação de grãos de pólen em espécies de fisális. Revista Ciência Agronômica 48: 365-373.

Sousa, V.A., Schemberg, E.A., Aguiar, A.V. 2010. Germinação in vitro do pólen de jerivá (Syagrus romanzoffiana (S.) Cham). Scientia Forestalis 38: 147-151.

Stanley, R.G., Linskens, H.F. 1974. Pollen: biology, biochemistry, management. Springer-Verlag Berlin, Heidelberg, Germany. 310 p.

Stumpf, E.R.T., Barbieri, R.L., Heiden, G. 2009. Cores e Formas no Bioma Pampa: plantas ornamentais nativas. Embrapa Clima Temperado, Pelotas, Brazil. 276 p.

Stumpf, E.R.T., Heiden, G., Iganci, J.R.V., Barbieri, R.L., Corrêa, L.B., Perleberg, T.D., Romano, C.M., Fischer, S.Z., Neitzke, R.S. 2012. Prospecting native ornamental plants in the brazilian pampa for use in landscaping and floral art. Acta Horticulturae 937: 1161-1166.

Thompson, A.H., Batjer, L.P. 1950. The effect of boron in the germinating medium on pollen germination and pollen tube growth for several deciduous tree fruits. Proceedings of American Society for Horticultural Science 56: 227-230.

Conflict of Interest Statement: The authors declare that the research was conducted in the absence of any commercial or financial relationships that could be construed as a potential conflict of interest.

All the contents of this journal, except where otherwise noted, is licensed under a Creative Commons Attribution License attribuition-type BY. 